\title{
Situācija Liepājā un tās apkārtnē 1905. gada revolūcijas priekšvakarāâ ${ }^{1}$
}

\author{
The Situation in Liepāja and its Surroundings \\ on the Eve of the Revolution of 1905
}

\author{
Aleksejs Kriška, Mg. hist. \\ Latvijas Universitātes Vēstures un filozofijas fakultāte \\ Aspazijas bulvāris 5, Rīga, LV-1050 \\ E-pasts:aleksejs.krs@gmail.com
}

Rakstā analizēta situācija Liepājā un tās apkārtnē 1905. gada revolūcijas priekšvakarā. Pētījums sniedz Liepājas pilsētas sociālekonomisko raksturojumu 19. un 20. gadsimta mijā, tajā arī apskatītas revolucionāro organizāciju aktivitātes un šajā saistībā Krievijas impērijas spēka struktūru veiktie pretdarbības pasākumi. Pētījumā iegūtā informācija palīdz izprast procesus, kas ḷāva revolucionārajām organizācijām nostiprināties un vēlāk ar panākumiem darboties Liepājā 1905. gada revolūcijas laikā, kā arī apstākḷus, kas liedza spēka struktūrām novērst revolucionārā noskaņojuma pieaugumu līdz 1905. gadam.

Atslēgvārdi: 1905. gads, revolūcija, spēka struktūras, Liepāja, žandarmērija, policija, Krievijas impērija, kontrabanda, propaganda.

The article is dedicated to the security situation in Liepāja and its surroundings on the eve of the Revolution of 1905. The author gives a socioeconomic description of Liepāja at the turn of the $20^{\text {th }}$ century, describes the activities of revolutionary organisations and countermeasures taken by Russian imperial security institutions in the aforementioned time and location. Information gained during the research helps to understand the processes, which allowed revolutionary organizations to gain a firm foothold in Liepāja and operate with success during the Revolution of 1905 , as well as circumstances that prevented the security institutions from averting the rise of revolutionary sentiment in the years prior to 1905.

Keywords: 1905, revolution, security institutions, Liepāja, gendarmerie, police, Russian empire, contraband, propaganda.

Kaut arī 19. gadsimta nogalē Krievijas impērijā joprojām aktīvi norisinājās industriālā attīstība, ilgstoši saglabājās vairāki neatrisināti sociālie jautājumi. Tikmēr no Rietumeiropas ieplūda sociālistiskas 
idejas, un šì plūsma pieauga līdz ar Krievijas impērijas emigrantu kopienu nostiprināšanos ārzemēs. Krievijas impērijas rūpnieciskajos un kultūras centros strādnieku un inteliǵgences vidū tika dibināti pulciņi ar sociālistisku un sociāldemokrātisku ievirzi, kuri vēlāk pārauga lielākās organizācijās. Straujā industrializācija un tai sekojošie sociālie sarežǵījumi skāra arī Liepāju, kas tobrīd bija izvirzịjusies par nozīmīgu eksporta ostu Krievijas impērijas Baltijas jūras piekrastes pašos rietumos. Arī tur veidojās aizliegtas politiskas organizācijas, kuras faktiski līdz ar to izveidi piesaistīja spēka struktūru uzmanību.

Šajā laikā tika pieņemts lēmums ziemeḷos no Liepājas izbūvēt Imperatora Aleksandra III kara ostu ${ }^{2}$ (turpmāk - kara osta), kuras aizsardzības nolūkos neilgi pēc tam tika uzsākti arī nocietinājumu sistēmas - Liepājas cietokšña - būvdarbi. Tādējādi 1905. gada revolūcijas priekšvakarā un arī pašas revolūcijas laikā tur atradās gan flotes, gan sauszemes karaspēka dalas. Taču, neskatoties uz karaspēka klātbūtni un policistu un žandarmu ilgstošu interesi, revolucionārie pulciṇi Liepājā turpināja attīstīties un izkopt savas darbības metodes. Līdz ar Krievu-japāņu kara sākšanos un tā nesekmīgo norisi revolucionārais noskaņojums 1904. gadā pieauga līdz iepriekš nepieredzētam līmenim. Atsevišķās karaspēka daḷās, tostarp arī Liepājā dislocētajās, auga dumpinieciskums, radot bažas par iespējamiem plašākiem nemieriem, kuros kopīgi iesaistītos gan revolucionārās organizācijas, gan sadumpojušies karavīri - scenārijs, uz kuru augstas cerības lika revolucionāri, taču tāds, kurš dažādu iemeslu dēl nerealizējās.

Tomēr 1905. gada sākumā revolucionāro organizāciju darbība Liepājas žandarmus un policistus pārsteidza ar savu vērienu un agresivitāti - apstākḷos, kad spēka struktūras jau gadiem sekoja līdzi šo organizāciju darbībai. Pastāvīgs informācijas trūkums un nespēja adekvāti reag̣ēt uz revolucionāru darbībām raksturoja faktiski visu spēka struktūru darbību līdz 1905. gada beigām - 1906. gada sākumam.

Vēsturiskajā literatūrā visplašāk atbildes uz jautājumiem saistībā ar 1905. gada revolūcijas norisēm ne tikai Liepājā, bet arī plašākā kontekstā ir snieguši šo norišu dalībnieki - revolucionāri - vai padomju autori, taču jāatzīst, ka tas ir visai vienpusīgs skatījums uz revolūcijas notikumiem. Kā piemēru var minēt apjomīgās "Latvijas revolucionāro cīnītāju piemiņas grāmatas" 1. sējuma $1 .{ }^{3}$ un $2 .{ }^{4}$ daḷu, kurās, lai gan plaši aprakstīti Latviešu sociāldemokrātiskās strādnieku partijas (LSDSP) biedru biogrāfiskie dati, tomēr bieži sagrozīta dažādu notikumu norise un to dalībnieku skaits, kā arī pārspīlēta LSDSP un Krievijas Sociāldemokrātiskās strādnieku partijas sadarbība, nepievēršoties citu revolucionāru organizāciju dalībnieku darbībai. Līdzīgi ir arī ar revolūcijas dalībnieka, vēlākā padomju drošības iestāžu darbinieka Kārḷa Landera darbu "1905. gada priekšvakarā", ${ }^{5}$ kas atsevišksos jautājumos papildina avotos pieejamo informāciju, taču kopumā ir vērtējams kā tendenciozs.

Lielu ieguldījumu dažādu nepatiesību un pārspīlējumu atklāšanā un tēmas izpētes veicināšanā ir snieguši Latvijas vēsturnieki Jānis Bērziņš, Līga Lapa un citi pētnieki, kuri kopš Latvijas neatkarības atgūšanas ir veltījuši laiku 1905. gada revolūcijas norišu izpētei, kā arī Krievijas pētnieki, kuru veikums palīdz notikumus mūsdienu Latvijas teritorijā un tādējādi arī Liepājā skatīt plašākā - Krievijas impērijas - kontekstā.

J. Bērziṇa rakstu sērijā Latvijas Vēstures Institūta Žurnālā ("Bruṇotās sacelšanās problēmas Latvijas pilsētās 1905. gada revolūcijā",, "Bruñotās sacelšanās problēmas Latvijas pilsētās 1905. gada revolūcijā (1. turpinājums)," "Bruṇotās sacelšanās problēmas Latvijas pilsētās 1905. gada revolūcijā (nobeigums)"”), kā nosaukums liecina, autors sniedz ieskatu brunotas 
sacelšanās īstenošanas problemātikā, pievēršoties gan spēka struktūru īstenotajiem drošības pasākumiem, gan revolucionāru darbībai Latvijas pilsētās, ietekmei uz karaspēku u. c. revolūcijas aspektiem. Lai gan rakstos informācija ir sniegta arī par norisēm citās Latvijas pilsētās, visvairāk J. Bērzinšs pievērsies notikumiem Rīgā, un tas ir likumsakarīgi, n,emot vērā to, ka Rīga bija revolucionāro organizāciju galvenais organizatoriskais un darbības centrs Latvijas teritorijā. Vērts atzīmēt, ka J. Bērziṇš ir arī veicis nozīmīgus pētījumus par Latvijas teritorijā dzīvojošo strādnieku darba un sadzīves apstākḷiem, ${ }^{9}$ kas papildina apskatāmā temata kopainu. Ievērojamu sniegumu 1905. gada revolūcijas norises izpētē ir sniegusi arī jau minētā vēsturniece L. Lapa, aprakstot notikumus Rīgā un Latvijas lauku teritorijās. Autores monogrāfija "Kaujinieki un mežabrāli 1905. gada revolūcijā Latvijā"10 ir aktuālākais un pēdējos gados apjomīgākais šāda veida darbs par revolūcijas norisi Latvijas teritorijā, kurā iekḷauts arī plašs revolūcijas norisēs iesaistīto personu rādītājs.

Attiecībā uz Krievijā publicētajiem darbiem vērts atzīmēt 2002. gadā izdoto rakstu krājumu "Krievijas žandarmi", 1 kurā ir apskatīti dažādi Krievijas impērijas žandarmērijas darbības aspekti - politiskā izmeklēšana, darbs ar slepeno aǵentūru, kā arī politisko noziegumu izmeklēšanas vēsture Krievijas impērijā kopumā. N̦emot vērā, ka Krievijas impērijas spēka struktūru strukturālie aspekti 1905. gada revolūcijas saistībā Latvijas historiogrāfijā ir apskatīti tikai fragmentāri, šādi darbi palīdz novērst informācijas trūkumus plašākā kontekstā, taču tajos trūkst detalizētas informācijas par lokālām norisēm impērijas regiionos.

Vērtīgs papildinājums priekšstatam par pirmsrevolūcijas laiku Liepājā ir Liepājas muzeja krājuma materiāli, kas attiecas uz revolucionāra Ernesta Rolava un Latviešu sociāldemokrātu savienības (LSS) darbību - korespondence, pieraksti un dažādu drukas darbu paraugi, kā arī materiāli, kas sniedz informāciju par sociālekonomiskajām pārmaiṇām pilsētā.

Ṇemot vērā publicētās informācijas trūkumu saistībā ar spēka struktūru darbību Liepājā un Latvijas teritorijā kopumā apskatāmajā laikā, pētījuma izstrādē tika izmantoti Latvijas Nacionālā arhīva Latvijas Valsts vēstures arhīva materiāli, no kuriem vērts pieminēt fonda "Kurzemes gubernas Žandarmērijas pārvalde (Jelgava, Kurzemes guberṇa)"12 materiālus, kas sniedz informāciju ne tikai par žandarmērijas, bet arī par policijas, karaspēka un slepenās aǵentūras darbību. Fondā ir atrodami spēka struktūrām izsūtītie cirkulāri, to savstarpējā korespondence, dažādas atskaites, novērojumi, revolucionāru liecības, notikumu atstāsti u. c. veida informācija.

Informāciju par pilsētas sociālekonomisko stāvokli apskatāmajā laikā sniedz 1897. gada Viskrievijas tautas skaitīšana. ${ }^{13}$ Avots palīdz izprast to, kādu iespaidu uz impērijas pilsētām atstāja industrializācijas procesi 19. gadsimta otrajā pusē. Pētījuma izstrādē tika izmantota arī Kurzemes guberņas Statistikas komitejas 1904. gadā izdotā "Kurzemes guberņas adrešu grāmata". ${ }^{14}$ Šis avots sniedz vispārīgu informāciju par valdības un pašvaldības struktūrām, sabiedriskajām organizācijām, baznīcu draudzēm, uzṇēmumiem un lauksaimniecībām, infrastruktūru, kā arī par guberṇā esošajām karaspēka, policijas un žandarmērijas struktūrām.

Kaut gan iepriekšminētie autori ir snieguši ieguldījumu vispārējā 1905. gada revolūcijas cēloṇu un norises analīzē, kā arī iesaistīto aktoru izpētē, situācijas attīstībai Liepājā gan revolūcijas laikā, gan tās priekšvakarā pētnieki ir pieskārušies tikai virspusīgi. Tādēḷ šis pētījums ir veikts, lai sniegtu ieskatu situācijā Liepājā un tās apkārtnē 1905. gada revolūcijas priekšvakarā, raksturojot revolucionāro organizāciju 
darbību un attīstību, kā arī pret šīm organizācijām vērstos spēka struktūru pretpasākumus - tādējādi pilnveidojot pieejamās informācijas kopumu par revolūcijas norisi Latvijas teritorijā. Pētījumā iegūtā informācija sniedz ieskatu arī sistemātiskos Krievijas impērijas spēka struktūru darbības trūkumos un klūuainos aprēkinos lokālā līmenī, taču pilnvērtīgākai izpratnei šajā saistībā ir vēlams sīkāks ieskats norisēs citviet Krievijas impērijā.

\section{Liepājas sociālekonomiskais raksturojums}

Priekšnoteikumi 20. gadsimta sākuma Liepājas sociālekonomiskajam portretam bija radušies jau iepriekšējā gadsimta pēdējā ceturksnī, kad, pateicoties Krievijas impērijas valdības lēmumam pielāgot Liepāju kā ostas pilsētu impērijas labības eksportēšanas vajadzībām, tika uzsākta Liepājas-Romnu dzelzceḷa līnijas izbūve un tirdzniecības ostas rekonstrukcija. Dzelzceḷa būvdarbi tika uzsākti 1869. gadā, un pilnīga satiksme visas $1313 \mathrm{~km}$ garās līnijas garumā tika atklāta 1874. gadā. ${ }^{15}$ Liepājas-Romnu dzelzceḷa izbūve sakrita ar intensīvo dzelzceḷa attīstību šajā laikā mūsdienu Latvijas teritorijā, kā arī Krievijas impērijā kopumā. Vien desmitgadi iepriekš tika atklāta Latvijas teritorijā pirmā ekspluatētā dzelzceḷa līnija RītupeDaugavpils (1860. gadā), kas bija Sanktpēterburgas-Varšavas dzelzcel̦a maǵistrāles posms. Savukārt gadu vēlāk, 1861. gadā, tika atklāts Rīgas-Daugavpils dzelzcel̦š. ${ }^{16}$ Kopumā 1850. gadā Krievijas impērijas dzelzceḷa līniju kopgarums bija 501 km, taču 1904. gadā tas bija sasniedzis jau $59616 \mathrm{~km},{ }^{17}$ ievērojami atvieglojot preču tranzītu, kā arī palielinot impērijas iedzīvotāju mobilitāti.

Pateicoties tam, ka Liepājas-Romnu dzelzceḷa izbūve nodrošināja vilcienu satiksmi uz Liepāju no attālām impērijas guberñām, Liepājas osta 19. gadsimta beigās kḷuva par vienu no galvenajiem Krievijas impērijas emigrācijas centriem. Sākotnēji izceḷotāju skaits no Liepājas bija neliels, taču ar laiku Krievijas impērijas pilsētās tika nodibinātas ārvalstu kuǵniecības uzñēmumu nodaḷas un aǵentūras, un emigrantu plūsma caur Liepāju pieauga. ${ }^{18}$ Tas savukārt bija vēl viens faktors Liepājas ekonomiskās augšupejas veicināšanā. Vērts arī atzīmēt, ka kopumā pēc preču apgrozības 19. gadsimta beigās Liepāja ieṇēma ceturto vietu Krievijas impērijas ostu vidū (aiz Odesas, Pēterburgas un Rīgas). ${ }^{19}$

Liepājas-Romnu dzelzceḷa līnijas izbūve un ar to saistītie tirdzniecības ostas rekonstrukcijas un paplašināšanas darbi nodrošināja arī Liepājas rūpniecisko uzplaukumu. Atvieglotā nepieciešamo izejvielu piegāde, nemitīgie būvniecības darbi pilsētā un tirdzniecības ostā, kā arī kara ostas izbūve nodrošināja labvēlīgus apstākl,us kokapstrādes, metālapstrādes un mašīnbūves uzñēmumu attīstībai. Latviešu konversācijas vārdnīcā norādīts, ka 1900. gadā Liepājā bija 32 fabrikas, ${ }^{20}$ no kurām dažās bija nodarbināti vairāki simti strādnieku. Kā lielākos uzṇēmumus 1904. gadā Liepājā var minēt "Vikandera un Larsona" korķa fabriku (500 strādnieki), mašīnbūves un tēraudliešanas rūpnīcu "Vezuvs" (199), mašīnbūves un tēraudliešanas rūpnīcu "Fēnikss" (147), baltmetāla izstrādājumu rūpnīcu "Foḷga" (250), ${ }^{21}$ sērkociṇu fabriku "Vulkāns" (230), metālapstrādes rūpnīcu "Bekers un Ko" (1322). ${ }^{22}$

Pilsētas rūpniecības uzñēmumi galvenokārt koncentrējās tirdzniecības ostas kanāla tuvumā vai arī Jaunliepājā (pilsētas ziemeḷu daḷa no tirdzniecības kanāla līdz pasažieru dzelzceḷa stacijai). Tur 19. gadsimta pēdējās desmitgadēs intensīvi norisinājās dzīvojamo ēku būvniecība pieaugošā pilsētas strādnieku skaita vajadzībām. Mājokḷu atrašanās rūpniecības uznēmumu 
tuvumā nodrošināja to, ka arī 20. gadsimta sākumā šì bija pilsētas strādnieku apdzīvotākā daḷa.

Vērts minēt, ka 1900. gadā 44\% no pilsētas strādniekiem bija nodarbināti metālrūpniecībā, 17\% - kịmiskajā rūpniecībā, 12\% - kokrūpniecībā, 10\% - pārtikas vielu pagatavošanā. ${ }^{23}$ Liels skaits Liepājas iedzīvotāju tika nodarbināts dzelzceḷa darbnīcās, tirdzniecības ostā (krāvēji, celtnieki u. c.), un, sākot ar 1890. gadu, arī kara ostas būvniecībā un vēlāk - kara ostas darbnīcās. ${ }^{24}$ 1904. gadā lielākā daḷa darbu kara ostā bija pabeigta, kā arī tur tika ierīkota atsevišksa pasta un telegrāfa nodaḷa. ${ }^{25}$ Tāpat paralēli kara ostas celtniecības darbiem, sākot ar 1895. gadu, norisinājās arī Liepājas cietokšn,a būvdarbi. ${ }^{26}$

Jāatzīmē, ka pēc 1897. gadā veiktās Viskrievijas tautas skaitīšanas datiem, kā Liepājā dzīvojoši tika uzskaitīti 64489 iedzīvotāji jeb $41,40 \%{ }^{27}$ no visa Kurzemes guberņas pilsētnieku skaita. ${ }^{28}$ Salīdzinājumam Jelgavā, kas apskatāmajā laikā bija Kurzemes guberņas administratīvais centrs, 1897. gadā tika uzskaitīts 35131 iedzīvotājs jeb 22,55\% no kopējā guberņas pilsētu iedzīvotāju skaita. ${ }^{29}$

Saskan̄ā ar Viskrievijas tautas skaitīšanas informāciju tobrīd Liepājā dzīvoja $19288(29,9 \%$ no pilsētas iedzivvotāju kopskaita) tur dzimušie, 22822 (35,4\%) iebraucēji no citiem Kurzemes guberņas apriṇķiem, 20535 (31,8\%) iebraucēji no citām guberṇām un 1844 (2,9\%) citu valstu piederīgie. ${ }^{30}$ Straujais iedzīvotāju skaita pieaugums un neproporcionāli lielais iebraucēju skaits ir skaidrojams ar iepriekšminēto pilsētas infrastruktūras un rūpniecības attīstību. Salīdzinājumā ar Rīgu, kur arī bija klātesoši šie faktori, iebraucēju īpatsvars tajā bija ievērojami mazāks (Rīgā dzimušie veidoja 39,8\% no pilsētas iedzīvotāju kopskaita). ${ }^{31}$ Tikpat liels iebraucēju īpatsvars kā Liepājā (ap 70\%) apskatāmajā laikā bija novērojams vēl tikai galvenajos
Krievijas impērijas centros - Maskavā un Sanktpēterburgā. ${ }^{32}$ Jāatzīmē, ka, ņemot vērā Liepājas pieaugošo lomu impērijas ārējos sakaros, tur darbojās arī vairāku valstu konsuli - ASV, Portugāles, Austroungārijas, Beḷgíijas, Nīderlandes, Brazīlijas, Francijas, Vācijas, Dānijas, Itālijas, Lielbritānijas, Griekijas, Spānijas un kopīgais Zviedrijas un Norvēgijas konsuls. ${ }^{33}$

\section{Revolucionāro organizāciju pirmsākumi Liepājā}

Iepriekšējā nodal̦ā raksturotajā situācijā 19. gadsimta pēdējās desmitgadēs ir meklējami arī revolucionārās kustības pirmsākumi Liepājā. Tur, līdzīgi kā Rīgā, Sanktpēterburgā un citās impērijas pilsētās, veidojās nelieli domubiedru - skolnieku, studentu, strādnieku - pulciņi, kuri, spriežot pēc pašu pulciṇu dalībnieku atmiṇām, 19.-20. gadsimta mijā galvenokārt nodarbojās ar tobrīd aktuālo sociālo, politisko un ekonomisko problēmu apspriešanu. ${ }^{34}$ Šo pulciṇu sapulces tika rīkotas slepus vai likumīgu pasākumu piesegā. Sākot ar 19. gadsimta 90. gadu vidu, pulciņu dalībnieki arvien plašāk aǵitēja pilsētas rūpniecības uznēemumu un ostas strādnieku vidū, kā arī apmeklēja dažādus nesaistītus sabiedriskus pasākumus, izvēršot tajos savu aǵitāciju. Aktīvi strādnieku pulciņi pirmsrevolūcijas laikā veidojās jau minētajos lielākajos pilsētas uzñēmumos - "Bekers un Ko", Vikandera un Larsona rūpnīcā u. c..$^{35}$

N̦emot vērā cilvēku pastāvīgo plūsmu gan no ārzemēm, gan no citām Krievijas guberṇām un impērijas lielajām pilsētām, Liepājas pulciṇu dalībniekus iespaidoja kā ārzemju idejas, tā arī idejas, kuras no citām impērijas guberṇām Liepājā ieveda augstskolu studenti un caurbraucošie emigranti. Jāatceras, ka 20. gadsimta sākumā Krievijas impērijā bija aizliegta jebkāda veida politiskā darbība, un līdz ar to nebija 
iespējams uzturēt likumīgas politiskās partijas, tādēḷ politiskās organizācijas bija spiestas darboties pagrīdē. ${ }^{36}$

Runājot par pagrīdes literatūru, pulciņu dalībnieki, tostarp arī Miķelis Valters, atzīmē, ka pārsvarā tā tika ievesta no ārzemēm, mazāk - no Iekškrievijas. ${ }^{37}$ Ar laiku revolucionāri nodibināja sakarus ar ārzemju tvaikoṇu jūrniekiem, kuri regulāri brauca no Liepājas uz Rietumeiropas ostām ${ }^{38}$ un ar kuru starpniecību revolucionāri apgādāja pagrīdes kustību ar Rietumeiropā iegūto sociālistisko literatūru. Arī paši Liepājas pulciṇu dalībnieki, sākot ar 19. gadsimta pēdējo desmitgadi, aktīvi iesaistījās nelegālās literatūras ievešanā. ${ }^{39}$ N̦emot vērā revolucionāro pulciṇu ierobežotās spējas un resursus, pagrīdes materiālu izplatīšana sākotnēji bija problemātiska - no Rietumeiropas atvestās ārzemju valodās rakstītās grāmatas, bukleti, pamfleti tika tulkoti, pārrakstot ar roku. ${ }^{40}$ Revolucionāru organizācijām attīstoties ārzemēs, Liepājas revolucionāri sāka saṇemt materiālus arī no tām. Piemēram, 1898. gadā Latviešu sociāldemokrāti Londonā izdeva brošūru "Nost ar "jaunajiem"”, kurā atspēkoti sociālistiem izteiktie pārmetumi, kā arī skaidrota sociālisma būtība un sociālistu organizāciju mērḳi. ${ }^{41}$ Tāpat 1899. gadā Klīvlendā, ASV, Liepājas Sociāldemokrātu savienība izdeva no krievu valodas pārtulkotu bukletu "Strādnieku organizāciju nozīme", ${ }^{42}$ kā arī skrejlapu "Atgādinājums latviešu strādniekiem un strādniecēm", ${ }^{43}$ kurā lasītāji tika aicināti gatavoties priekš nākotnē paredzētās bruṇotās sacelšanās.

Informācija par to, kad Liepājā tika ierīkotas pirmās pagrīdes tipogrāfijas, ir skopa. Revolūcijas dalībnieks K. Landers min, ka viena šāda tipogrāfija, kas nodarbojās ar pamfletu drukāšanu un izplatīšanu, esot pastāvējusi 1903. gadā kāda zvejnieka mājā. ${ }^{44}$ Zināms, ka spēka struktūras šīs tipogrāfijas aktīvi meklēja, reti gūstot panākumus.
Ieskicējot to, kā norisinājās nelegālās literatūras ievešana no ārzemēm, jāatzīmē, ka šādas kontrabandas operācijas bija riskantas un prasīja zināmu iepriekšēju sagatavošanos. Savstarpējā sarakstē revolucionāri sazinājās šifrēti, pārvietojās ar viltotiem dokumentiem, kā arī pēc iespējas mainīja savu ārējo izskatu. ${ }^{45}$ Šajā kontekstā jāizceḷ 1903. gada 20. jūnija ${ }^{46}$ Policijas departamenta Sevišǩās nodaḷas vēstule Kurzemes gubernas Žandarmērijas pārvaldes priekšnieka palīgam Grobinas aprinkīì un Liepājas ostā Aleksandram Mezencevam tajā minēts, ka Policijas departamenta rīcībā bija nonākusi informācija par Liepājas pasu biroju, kas darbojas revolucionāru, tostarp arī Kijevā esošas organizācijas,

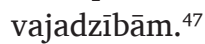

Veicot pārvadājumus Vācijas impērijas pierobežā, pirms operācijas īstenošanas kontrabandisti izlūkoja maršrutus apvidū, kā arī izpētīja apkārtnes kartes. ${ }^{48}$ Zināms, ka otrpus robežai kontrabanda tika organizēta Klaipēdā, ${ }^{49}$ no kurienes sūtījumi vēlāk nonāca Palangā vai pierobežas ciemos, un vēlāk tie tika transportēti uz Liepāju vai citām impērijas pilsētām. Kā alternatīva pārvadājumiem no tuvējās Vācijas impērijas teritorijas pa sauszemi bija kontrabandas transportēšana nakts aizsegā pa jūru, izmantojot laivas. Lai gan šāda kontrabandas pārvadāšanas metode tika uzskatīta par ātrāku, tā bija arī riskantāka. Braucot ar laivām naktī, kontrabandisti darbojās faktiski bezorientieru apstākḷos. Laikapstākḷu pārmaiņas un mānīgas jūras straumes varēja ierobežot laivu kustību, liedzot tām pārvarēt nepieciešamo attālumu noteiktajā laikā. Tā, piemēram, 1904. gada pavasarī krievu tautības kontrabandistu grupu pludmalē pārsteidza kāds karavīrs. Viṇu pamanot, kontrabandisti nometa dalu no kravas un bēga, taču vēlāk tika aizturēti kādā netālu esošā īpašumā. ${ }^{50}$

Sadarbība starp revolucionārajām organizācijām kontrabandas jautājumos bija 
sarežǵīta. Revolucionārs, viens no LSS dibinātājiem, E. Rolavs, kādā vēstulē atzīmēja, ka darbību pierobežā apgrūtināja nesadarbošanās un konkurence ar citām kontrabandistu grupām, un izcēla kādu "tolstojiešu zagḷu bandu". ${ }^{51}$ Tāpat viņš kritizēja to, ka revolucionāru laikraksti publicēja tendenciozus materiālus, nevis koncentrējās uz konceptuālākām problēmām, kas vienotu visu tautību izcelsmes strādniekus, revolucionārus. E. Rolavs arī minēja, ka revolucionāru organizācijas savstarpēji cīnījās par ietekmi un cilvēkiem, kā arī aǵitēja cita pret citu. ${ }^{52}$ Vērts atzīmēt, ka šie kontrabandas tīkli un pazīšanās revolūcijas laikā bija noderīgi ne tikai pretlikumīgu drukas materiālu, bet arī apbruṇojuma ievešanā Krievijas impērijas teritorijā.

Zināms, ka 20. gadsimta pirmajos gados arvien vairāk tika izplatīti vietējo organizāciju drukātie materiāli, piemēram, buklets "Militārisms un strādnieku škira", ko Latviešu sociāldemokrātu grupa Kurzemē 1903. gadā pārtulkoja no krievu valodas. ${ }^{53}$ Saistībā ar imperatora Nikolaja II (Nikolaj II Romanov) vizīti Liepājā 1903. gadā par godu Nikolaja jūras katedrāles iesvētīšanai revolucionāri izplatīja uzsaukumu "Liepājas strādniekiem", kurā imperatora vizīte tika kritizēta par lieku naudas izškēērdību, kā arī Liepājas sociāldemokrātu strādnieku organizācija aicināja Liepājas iedzīvotājus vizītes laikā dziedāt revolucionārās dziesmas. ${ }^{54}$ Revolucionāru propaganda bija izplatīta ne tikai pilsētā, bet arī tai piegulošajā lauku apvidū. Līdzīgus materiālus kā minētos, tikai ar agrāru ievirzi Liepājas apkārtnē izplatīja, piemēram, Latviešu revolucionāro zemnieku pulcins.s. ${ }^{55}$

Lai gan historiogrāfijā šajā saistībā pārsvarā tiek apspriesta latviešu revolucionāru darbība, avoti liecina, ka pirmsrevolūcijas gados Liepājā aktīvas bija arī krievu revolucionāru organizācijas, tostarp Krievijas Sociālrevolucionāru partija jeb Krievijas eseri. Piemēram, latviešu revolucionāri galvenokārt savu aǵitāciju izvērsa latviešu izcelsmes vai latviski runājošo pilsētas un lauku iedzivotāju vidū, taču krievu revolucionāru mērḳgrupa bija strādnieki - iebraucēji, bet ar Krievu-japāṇu kara sākšanos arvien lielākos apjomos propagandas materiāli tika izplatīti arī karavīru vidū. Arī šo organizāciju skrejlapās un brošūrās, līdzịi kā latviešu revolucionāru izplatītajos materiālos, tika kritizēta monarhija. Kā piemēru var minēt skrejlapu ar sevišḳi dzēlīgu nosaukumu (krievu. val.) "Nikolajs II un pēdējais, Obmanovs, Šliselburgas, Pētera un Pāvila, Sibīijas bende un tā tālāk, un tā tālāk, un tā tālāk...",56 kurā tika kritizēta Nikolaja II izcelsme, kā arī politiskā darbība. Sākoties Krievu-japāṇu karam, Krievijas eseri izplatīja brošūras ar politiskām dziesminām, piemēram, bukletu (krievu val.) “"Bēdiṇa” Dziesma par Krievu-japāṇu karu”, kurā satīriski tika kritizēti Krievijas impērijas ārpolitiskie motīvi, brunoto spēku stāvoklis un sociālā nevienlìdzība valstī. ${ }^{57}$

Krievu-japāņu kara nesekmīgā norise vairoja neapmierinātību Liepājā dislocēto zemāko pakāpju militārpersonu vidū, sevišķi kug̣u apkalpēs. Rezultātā līdztekus pieaugošajai pretvalstisko politisko organizāciju darbībai un iedzīvotāju neapmierinātîbai ar valdības nespēju vai nevēlēšanos risināt sociālekonomiskās problēmas arī karaspēkā arvien biežāk izpaudās neapmierinātība ar dienesta apstākḷiem. Arvien izteiktāk karavīri pauda nevēlēšanos tikt iesaistīti karadarbībā.

Jau 1904. gada 27. janvārī (dienā, kad sākās Krievu-japāṇu karš) Liepājā, cietokšña teritorijāa , kā arī kara ostā tika atrastas 34 proklamācijas, no kurām septiṇas bija krievu, 16 - lietuviešu un 11 - latviešu valodā. ${ }^{58}$ Pēdējās divas grupas bija paredzētas kara ostas darbnīcu strādniekiem, n,emot vērā, ka vairums to strādnieku bija vietējas izcelsmes (piemēram, proklamācija 
"Liepājas lietuviešu strādniekiem" lietuviešu valodā vai "Visa Rīga smird!" - latviešu valodā). Tonakt pilsētas gorodovoji divas personas - proklamāciju izplatītājus - izsekoja un aizturēja, ${ }^{59}$ taču šādi gadījumi gan pirms revolūcijas, gan tās laikā bija reti. Acīmredzot proklamāciju izplatītāji bija pietiekami piesardzīgi, kā arī pārzināja savu darbības vietu un bieži varēja rēḳināties ar apkārtējo atbalstu, jo nereti paši nāca no vides, kurā darbojās. 1904. gada 28. janvārī proklamācijas tika izsvaidītas arī dzelzceḷa darbnīcās un pilsētas fabrikās, ${ }^{60}$ savukārt jau 10. februārī kara ostā tika salasīts kopumā 101 uzsaukums karavīriem pret karu. ${ }^{61}$ Nevienā no šiem gadījumiem proklamāciju izplatītāji uz vietas netika aizturēti - spēka struktūrām netīkama tendence, kas saglabājās arī visu 1905. gadu.

Vēl 1904. gada februāra un marta mijā žandarmērijas darbinieki Liepājā veica kratī̌anas pie aptuveni 40 personām, veicot arestus un bez panākumiem meklējot pagrīdes tipogrāfijas. ${ }^{62}$ Savukārt revolucionāri šìs spēka struktūru neveiksmes aprakstīja savos izdevumos, tādējādi spēka struktūru darbību diskreditējot. Proklamāciju izplatīšana pieauga ne tikai kara ostā, bet arī pašā pilsētā - lielajos rūpniecības uzṇēmumos, darbnīcās un dažādos sabiedriskos pasākumos. Piemēram, 1904. gada 24. oktobrī pēc rīta dievkalpojuma sv. Annas baznīcā revolucionāri baznīcas apmeklētāju pūlì izmētāja proklamācijas un, ņemot vērā lielo cilvēku skaitu un burzmu, nemanīti pameta apkārtni. ${ }^{63}$

\section{Spēka struktūras un to darbība}

Interesi par revolucionārajām organizācijām spēka struktūras sāka izrādīt faktiski vienlaicīgi ar šo organizāciju izveidi. Pirmsrevolūcijas laikā ar pretdarbību revolucionārajai kustībai Liepājā un tās tuvākajā apkārtnē nodarbojās galvenokārt policijas, žandarmērijas un robežsardzes darbinieki.

Apskatāmās tēmas kontekstā kā savās darbības jomās visaptverošākais jāmin tieši Policijas departaments. Tā atbildībā bija ne tikai sabiedriskās kārtības nodrošināšana, bet arī izlūkošana un slepenas aǵentūras uzturēšana gan ārvalstīs, gan valsts iekšienē. Ārējo informāciju sākotnēji vāca savervētie ārzemnieki, taču vēlāk šajā procesā arvien vairāk tika iesaistīti Krievijas impērijas iedzīvotāji. Ārvalstīs sevišḳa uzmanība tika pievērsta Krievijas impērijas politisko emigrantu darbībai. Ar informācijas vākšanu to aprindās galvenokārt nodarbojās Krievijas impērijas pilsoṇi, darbojoties tādu pašu politisko emigrantu piesegā. ${ }^{64}$ No šìm personām Policijas departaments saṇēma arī informāciju par kontrabandistiem, to sūtījumiem un maršrutiem, ${ }^{65}$ galvenokārt no Eiropas pilsētām - Berlīnes, Bernes, Parīzes u. c., kā arī no ASV. ${ }^{66}$

Darbu ar slepeno aǵentūru organizēja un koordinēja Policijas departamenta Seviškāā nodala, taču Krievijas impērijā uz vietas ar aǵentiem darbojās guberṇu žandarmērijas pārvaldes, vēlāk arī apsardzības nodaḷas jeb tā saucamās "ohrankas" (Liepājā "ohranka" tika izveidota tikai 1906. vai 1907. gadā; ${ }^{67}$ zināms, ka Rīgā šãda nodaḷa pastāvēja līdz 1911. gadam ${ }^{68}$ ). Pirmsrevolūcijas laikā tika paredzēts, ka slepeno aǵentūru būs iespējams izmantot ne tikai informācijas iegūšanai par revolucionāro organizāciju iekšējām norisēm, bet arī organizāciju darbību ietekmēšanai spēka struktūrām vēlamā veidā. Vairākkārt tika uzsvērta nepieciešamība izvērst aǵentu tīklus visās impērijas lielajās pilsētās un rūpnieciskajos centros, lai panāktu rezultātus, kas mazāk balstītos uz veiksmi, vairāk uz stingru sistemātisku darbu, ${ }^{69}$ taču, neņemot vērā dažādus mēgeinājumus sekmēt aǵentu darbību, lielākais apgrūtinājums bija revolucionāro organizāciju 
īstenotie pasākumi, kas bija tieši vērsti uz šādu aǵentu atklāšanu.

Pieminēšanas vērts ir arī 1903. gada 20. marta Policijas departamenta Sevišķās nodaḷas izplatītais cirkulārs guberṇu žandarmērijas pārvalžu priekšniekiem, kurā žandarmērijas darbinieki, nopratinot slepenos aǵentus, tika aicināti ievērot visus nepieciešamos drošības mērus, jo vairākkārt bija konstatēti gadijumi, kad aǵenti žandarmu nolaidības dēḷ tikuši kompromitēti. ${ }^{70}$ Tāpat tika aicināts aǵentus neuzrunāt žandarmērijas pārvalžu telpās, kur tiem bija iespēja satikt aizdomās turamās, novērotās vai novērojamās personas, kam acīmredzami arī iepriekš bijuši precedenti.

Policijas departaments sevišḳu uzmanību pievērsa arī revolucionāru korespondencei, veicot perlustrāciju. Lai gan oficiāli korespondences perlustrācija bija pretlikumīga, tas bija viens no efektīvākajiem sabiedrības novērošanas veidiem. ${ }^{71} \mathrm{Ar}$ to nodarbojās Policijas departamenta perlustrācijas punkti. Zināms, ka 1880. gadā Krievijas impērijā pastāvēja septiṇi šādi punkti: Harkovā, Kijevā, Maskavā, Odesā, Sanktpēterburgā, Tbilisi un Varšavā. Vēlāk šādi punkti neilgi darbojās arī Kazaņā, N̦ižņijnovgorodā, Rīgā, Tomskā un Viḷnā. Perlustrācija tika turēta lielā noslēpumā, un darbinieku vidū pastāvēja mutiska vienošanās, ka nemieru gadījumā ar to saistītie dokumenti jāiznīcina ${ }^{72}$ - tādējādi izskaidrojams, kādēḷ tik daudzi perlustrācijas punktu dokumenti tika iznīcināti revolūcijas laikā.

Vietējā mērogā Liepājas gadījumā ir zināms, ka saskaṇā ar 1891. gada 26. aprîlī Valsts padomes apstiprināto likumu "Par Liepājas pilsētas policijas štatu" šajā gadā Liepājas policijas pārvaldē skaitījās 97 darbinieki, ${ }^{73}$ savukārt, kā raksta vēsturniece Dzidra Ozolina, līdz 1905. gadam šis skaits bija palielinājies līdz 110, kas bija par 30 darbiniekiem vairāk nekā noteikts 1891. gadā apstiprinātajā štatu sarakstā. ${ }^{74}$
1904. gadā policijas darbību Liepājā koordinēja Liepājas pilsētas policijas pārvalde (priekšnieks barons Pāvels Fītinghofs-Šēls), kurai bija pakḷauti četri pilsētas rajonu iecirkņi un atsevišks ostas iecirknis. ${ }^{75}$ Pilsētas policijas darbinieki jeb gorodovoji galvenokārt bija atbildīgi par sabiedriskās kārtības uzturēšanu, taču nepieciešamības gadījumā (apskatāmajā laikā arvien biežāk) sadarbojās ar žandarmērijas darbiniekiem.

Žandarmērija jeb, precīzāk - Atseviškais žandarmu korpuss, bija specializēta struktūra, kuras darbinieki bija atbildīgi par nelikumīgi sapulcējušos cilvēku izkliedēšanu, politisko noziegumu izmeklēšanu (arī karaspēka daḷās) u. tml. darbībām, kuru īstenošanā Atseviškais žandarmu korpuss bija pakḷauts iepriekšminētajam Iekšlietu ministrijas Policijas departamentam, savukārt personālsastāva komplektēšanas un nodrošinājuma jautājumos - Kara ministrijai. ${ }^{76}$ Korpusu vadīja galvenā pārvalde, un tās pakḷautībā bija dzelzceḷa žandarmu policijas pārvaldes, apgabalu žandarmu pārvaldes, guberṇu žandarmu pārvaldes u. c. atseviškas struktūras. ${ }^{77}$ Pirmās guberṇu žandarmu pārvaldes tika izveidotas vēl 1867. gadā. To galvenie uzdevumi bija tādi paši kā Atsevišķajam žandarmu korpusam kopumā, taču 19.-20. gadsimta mijā tās arvien vairāk koncentrējās tīri uz politiska rakstura lietām. ${ }^{78}$ Žandarmu policijas dzelzceḷa pārvaldes tika izveidotas vēl 1861. gadā, un to atbildībā bija kārtības uzturēšana dzelzceḷa maršrutos un dzelzceḷa līnijām piegulošajās teritorijās. Lai gan oficiāli dzelzceḷa žandarmu policijas pārvaldes darbinieki revolucionārās kustības apspiešanā netika iesaistīti līdz 1906. gadam, ${ }^{79}$ daudzviet, tostarp arī Liepājā, pretdarbībā revolucionāru aktivitātēm tos iesaistīja arī agrāk.

Liepājas žandarmērijas nodaḷa, kuru vadīja iepriekš minētais Kurzemes gubern,as žandarmērijas priekšnieka palīgs Grobiṇā un Liepājas ostā - apakšpulkvedis 
A. Mezencevs, bija atbildīga par Liepājas pilsētu, Palangu, Grobiṇas apriṇķi un daḷēji arī Aizputes apriṇki. Visas šis teritorijas nosegšanai A. Mezencevam bija pakḷauti 12 apakšvirsnieki, no kuriem 10 bija Liepājā (pieci bija pastāvīgie, pieci - piekomandētie), bet divi - Palangā. Pirmsrevolūcijas laikā šie darbinieki seviški pievērsa uzmanību norisēm ostā, revolucionāriem reemigrantiem, kā arī dažādo revolucionāro pulcinu darbībai. ${ }^{80}$

Paralēli A. Mezenceva vadītajai nodaļai darbojās Liepājas cietokšn,a žandarmu komanda un žandarmu komanda Imperatora Aleksandra III kara ostā. ${ }^{81}$ Lai gan šĩs abas komandas atradās A. Mezenceva nodaḷas atbildības rajonā, tās bija nepastarpināti pakḷautas Kurzemes guberņas Žandarmērijas pārvaldes priekšniekam. ${ }^{82}$ Atsevišķi par sabiedrisko kārtību uz dzelzceḷa un tam piegulošajā teritorijā Liepājas-Romnu dzelzceḷa (posms no Liepājas līdz Šauḷiem) un Liepājas-Aizputes dzelzceḷa posmos bija atbildīga Liepājas-Romnu dzelzceḷa un Liepājas-Aizputes dzelzceḷa Žandarmu policijas pārvalde rotmistra Jevgēnija Kaḷn,icka (Evgenij Kal'nickij) vadībā, kas savukārt bija tieši pakḷauta Minskas dzelzceḷa Žandarmu policijas pārvaldei. ${ }^{83}$ Tādējādi, lai gan teorētiski visas šīs apakšstruktūras bija pakḷautas vienai institūcijai, administratīvie sarežǧijjumi un apakšstruktūru iedalījums, kas nebija atbilstošs situācijai Liepājā un tās apkārtnē, apgrūtināja žandarmērijas nodaḷu savstarpējo sadarbību.

Valsts pierobežā ar pretdarbību revolucionāru aktivitātēm nodarbojās Krievijas Atsevišķais robežsardzes korpuss. Miera laikā tas bija Finanšu ministrijas pakḷautībā, taču kara izsludināšanas gadỉjumā to bija paredzēts pakḷaut Kara ministrijai. ${ }^{84}$ Robežsargi galvenokārt nodarbojās ar nelegālo robežu šḳērsotāju aizturēšanu, kā arī kontrabandas apkarošanu un izlūkošanu pierobežā. ${ }^{85}$ Tiem tika uzdots sekot līdzi no impērijas izbraucošajiem revolucionāro organizāciju dalībniekiem, pēc iespējas robežsargus informēja gan par personu piederību konkrētai organizācijai, galamērkiem ārzemēs, kā arī grupējumiem, kas tur darbojās. Pirmsrevolūcijas gados un sevišķi revolūcijas laikā robežsardzes darbiniekiem revolucionāru kustībai tika uzdots pievērst pastiprinātu uzmanību, jo tika gaidīta paaugstināta politisko emigrantu atgriešanās Krievijas impērijā. ${ }^{86}$

Sevišku uzmanību spēka struktūras vēl pirmsrevolūcijas gados pievērsa arī ieceḷojošajiem ārzemniekiem. Sistemātiski tika ievākta un apkopota informācija par personu identitāti, uzturēšanās ilgumu, iemesliem un vietu, kā arī tika novērotas šo personu aktivitātes uzturēšanās laikā Krievijas impērijā. ${ }^{87}$ Tāpat spēka struktūras darīja visu, lai nepiel̦autu nevēlamu ārzemnieku ierašanos Krievijas impērijā. Piemēram, 1901. gada novembrī Policijas departaments izplatīja cirkulāru, kurā tika uzskaitīti 310 ārzemju anarhisti, kurus tika aizliegts ielaist impērijas robežās. ${ }^{88}$ Tiesa, aprakstoša informācija, neskaitot vārdus un uzvārdus, par šìm personām bija krietni skopāka nekā par Krievijas impērijas pilson,iem, kas bija nonākuši spēka struktūru interešu lokā. Novērotas tika arī par dažādiem pārkāpumiem, tostarp politiskiem, amnestētās personas, kas bija ieradušās vai atgriezušās Liepājā vai tās apkārtnē. ${ }^{89}$

Līdzīgi hierarhiski sarežǵijumi kā žandarmērijā bija arī robežsardzē, kas bija vistiešāk iesaistīta pretdarbībā revolucionāru kontrabandai un revolucionāru izcel̦ošanai no Krievijas impērijas un ieceḷošanai tajā. Kurzemes guberṇas robežsardze bija pakḷauta Atseviškā robežsardzes korpusa 2. apgabala Rīgas brigādei. Liepājā darbojās Rīgas brigādes 3. nodaḷa, atsevišķi Liepājas nodaḷa, kā arī tur bija dislocēts robežsardzes kreiseris Straž. ${ }^{90}$ Taču uz dienvidiem no Liepājas, Palangā, kuras apkaimē aktīvi darbojās kontrabandistu grupas, atradās Palangas robežsardzes nodaḷa, 
kas bija pakḷauta pavisam citai vienībai 5. Gargždu brigādei. ${ }^{91}$

Sarežğìjumus spēka struktūrās radīja arī birokrātiska rakstura nesaprašanās, tostarp problēmas ar naudas līdzekḷu pieškiršanu, apgrūtinot aǵentu vervēšanu un to darbības apmaksāšanu. Liepājas žandarmērijas nodaḷas gadījumā, lai mazinātu naudas līdzekḷu piegādes aizkavēšanās sekas, apakšpulkvedis A. Mezencevs vairākkārt bija spiests apmaksāt savas nodaḷas tērinuus no personīgajiem līdzekliem. ${ }^{92}$

1902. gada 13. augusta Policijas departamenta cirkulārā impērijas gubernu žandarmērijas pārvalžu priekšniekiem atzīmēta pakāpeniska drošības situācijas pasliktināšanās - pretvalstisko pulciṇu darbības pieaugums, sistemātiska nelegālās literatūras kontrabanda no ārzemēm, kā arī liela sociāldemokrātisko ideju ietekme uz strādniekiem. Kā galvenā problēma minēts fakts, ka, nelegālajiem pulciniem veidojot ciešākus sakarus un apvienojoties lielākās organizācijās, kḷuva arvien grūtāk piesaistīt tos konkrētām vietām un savlaicīgi apturēt revolucionāru darbību. ${ }^{93}$ Lai ierobežotu revolucionāru mobilitāti un paaugstinātu iespējas veikt pretvalstisko aktīvistu aizturēšanas arī ārpus viṇu organizāciju darbības vietām, Policijas departamenta Seviškā nodaḷa gubernatoriem, pilsētu priekšniekiem, policijas pārvalžu priekšniekiem, guberņas žandarmērijas un dzelzceḷa žandarmu policijas pārvaldes priekšniekiem, kā arī uz robežpunktiem sūtīja cirkulārus, kuros tika sniegta informācija par personām, kas tobrīd atradās meklēšanā, par iepriekš meklēto personu aizturēšanām, kā arī par revolucionārās kustības attīstību un revolucionāru aktivitātēm gan Krievijas impērijā, gan ārpus tās. ${ }^{94}$ Piemēram, 1902. gada 1. februāra cirkulārā minēts, ka Kurzemes guberṇas Žandarmērijas pārvalde par politiskās kontrabandas ievešanu turēja aizdomās (Emīlu) Eduardu Skubiḳi, M. Valteru, Frīdrihu (Frici) Roziṇu un Edvardu
Pavlovski. Viṇu atklāšanas gadījumā tika uzdots vinus arestēt un nogādāt Liepājā A. Mezenceva uzraudzībā. ${ }^{95}$

Kā jau minēts, Policijas departaments pēc iespējas izsūtīja fotokartītes un detalizētus aizdomās turamo personu aprakstus. ${ }^{96}$ Blakus informācijai par aizdomās turamo dzīvesvietu, nodarbošanos, tautību un izcelsmi aprakstos tika sniegta arī sīka informācija par šo personu mīmiku, garīgajām un fiziskajām īpašībām - kermena un sejas uzbūvi, izmaināâm sejas vaibstos runāšanas laikā, plaušu tilpumu u. c. ${ }^{97}$ Kā piemēru var minēt M. Valtera aprakstu no 1899. gada 10. jūlija Policijas departamenta cirkulāra, kurā minēti viṇa gímenes locekḷi, izglītība, nodarbošanās, augums, miesasbūve, matu krāsa, biezums un uzbūve, acu krāsa, redzes kvalitāte, balss skal̦ums un zobu salikums runas laikā. Šajā cirkulārā M. Valtera pamanīšanas gadijjumā tika noteikts vinu arestēt un nodot Vjatkas gubernatora rīcībā, informējot par to Policijas departamentu. Tāpat vērts atzīmēt, ka M. Valters tika turēts aizdomās par "sociāldemokrātiska rakstura propagandas izplatišanu Vidzemes un Kurzemes zemnieku vidū". ${ }^{98}$ Šajā pašā cirkulārā līdzīgs apraksts ir atrodams arī par F. Roziņu, kuru savukārt tika uzdots nodot Sanktpēterburgas pilsētas priekšnieka rīcībā. ${ }^{99}$

Spēka struktūras veica novērošanu arī ostā, darbnīcās un rūpniecības uzṇēmumos. Oficiāli to aǵenti kontrolēja strādnieku darba apstākḷus, taču patiesībā to uzdevums bija atklāt un arestēt aǵitatorus, pirms tie radīja nemierus. ${ }^{100}$ Pēc apskatītajiem avotiem var noprast, ka tik ilgi, kamēr revolucionāru organizācijas nebija izkopušas savas darbības metodes, šo aǵentu pienesums pretlikumīgas darbības atklāšanā bija ievērojami lielāks. Tā, piemēram, kāds revolucionārs par savu aizturēšanas laiku atzīmēja, ka nopratināšanas laikā žandarmērijas virsnieks bijis informēts gan par privātu revolucionāru sarunu saturu, 
gan arī to, kā revolucionāri bija mācījušies savstarpēji sarakstīties, izmantojot šifrus. ${ }^{101}$ Cietumos ziņotāji bija gan paši ieslodzītie, gan arī škietami draudzịgie uzraugi, kas provocēja aizturētos uz nepārdomātiem izteikumiem. ${ }^{102}$ Lai ierobežotu revolucionāru darbību Liepājā, apcietinātās personas pēc iespējas tika fotografētas. Ir zināms, ka 1904. gada martā Kurzemes guberṇas Žandarmērijas pārvaldei tika pieškirti līdzekḷi 150 rubḷu apmērā slepeno aǵentu uzturēšanai un darbības nodrošināšanai, žandarmērijas apakšvirsnieku dienesta tēriņiem, fotokartīšu taisīšanai, ekspertīžu veikšanai un transporta pakalpojumu izmantošanai ārkārtas situāciju gadījumā. Papildu līdzekl̦us bija iespējams iegūt, uzrādot atskaites par iepriekšējās summas iztērēšanu. ${ }^{103}$

Seviška uzmanība tika pievērsta arī revolucionārā noskaņojuma izplatībai spēka struktūru darbinieku vidū. Jau minētais E. Rolavs 1900. gada 10. decembrī rakstīja, ka iepriekš trīs cietumsargi un divi gorodovoji esot tikuši arestēti par sociālistiska rakstura literatūras lasǐšanu. ${ }^{104}$ Šeit jāatzīmē, ka apskatītie materiāli, konkrēti - policijas darbinieku un žandarmu ziņojumi, liecina, ka revolucionārās kustības apspiešanā iesaistīto spēka struktūru darbinieku sadarbošanās gadījumi ar revolucionāriem pirmsrevolūcijas laikā bija reti un, iespējams, dažkārt vienkārši netika konstatēti. Situācija Liepājā mainījās 1905. gadā, kad revolucionārā noskaņojuma uzplūdā sākās uzbrukumi spēka struktūru darbiniekiem, vardarbīgas sadursmes un vispārējs sabiedriskās drošības kritums Liepājā un tai piegulošajā lauku apvidū. Pastāvīga dzīvības apdraudējuma, revolucionāro ideju vai citu apstākḷu iespaidā revolūcijas laikā tika novērota atsevišḳu spēka struktūru darbinieku, kā arī citu iestāžu amatpersonu nolaidība vai atklāta nevēlēšanās pildīt savus pienākumus, nodrošinot labvēlīgus apstākḷus revolucionāro organizāciju darbībai arī turpmāk.

\section{Secinājumi}

Kā ilustrē Liepājas piemērs, Krievijas impērijas spēka struktūru īstenotie pretdarbības pasākumi sniedza tikai īstermiņa panākumus revolucionāro organizāciju darbības ierobežošanā. Līdzīgi kā citviet Krievijas impērijā, arī Liepājā revolucionārās organizācijas laika gaitā izkopa savu darbības metodiku, nodrošinot sev pietiekami labvēlīgus apstākḷus sekmīgai pagrīdes darbībai. Kaut arī Liepājā aktīvo revolucionāro organizāciju mērḳi bija radniecīgi, atsevišķos jautājumos, piemēram kontrabandas pārvadāšanā un iedzīvotāju atbalsta gūšanā, tās savstarpēji konkurēja.

Spēka struktūru īslaicīgie panākumi galvenokārt balstījās uz aǵentu sekmīgu darbību - gan ārvalstīs, gan uz vietas. Par pilsētas iebraucējiem, kā arī iespējamiem vietējiem revolucionāriem tika sistemātiski ievākta un impērijas līmenī starp spēka struktūrām izplatīta informācija, kas atsevišķos gadījumos veicināja aizdomās turamo indivīdu aizturēšanu. Taču, pieaugot revolucionāru grupu organizētībai un piesardzībai (tostarp veicot dažādas uz spēka struktūru aǵentu atklāšanu vērstas darbības), spēka struktūrām pieejamās informācijas daudzums par šīm grupām kḷuva arvien ierobežotāks, savukārt esošā informācija nebija pietiekama, lai spēka struktūrām nodrošinātu vēlamos rezultātus. Kā uzskatāmu spēka struktūru neveiksmi Liepājā var minēt nespēju atklāt un apturēt vietējo pagrīdes tipogrāfiju darbību un novērst revolucionāro organizāciju propagandas materiālu izplatību.

N̦emot vērā to, ka revolucionāro organizāciju būtība sakṇojās neatrisinātajos Krievijas impērijas sociālajos jautājumos, spēka struktūru darbība lokālā līmenī, šajā gadījumā - Liepājā un tās apkārtnē, atstāja mazu iespaidu uz revolucionārās kustības tālāko attīstību, un atsevišksos jautājumos (kontrabanda, revolucionāru savstarpējā 
korespondence, mobilitāte u. c.) radīja pretēju efektu, l̦aujot vietējām revolucionāru organizācijām atklāt un izskaust trūkumus savā darbībā. Stāvokli pilsētā ievērojami pasliktināja arī Krievu-japān,u kara nesekmīgā norise, negatīvi iespaidojot tur dislocētos karavīrus un iedrošinot revolucionārus arvien aktīvāk izvērst savu darbību.

\section{ATSAUCES UN SKAIDROJUMI}

${ }^{1}$ Raksta pamatā ir autora maǵistra darbs "1905. gada revolūcijas norise Liepājā: represīvo institūciju darbība” (Latvijas Universitāte, 2018), darba zinātniskais vadītājs: profesors Ēriks Jēkabsons.

2 Šāds nosaukums kara ostai tika piešḳirts saskaņā ar imperatora Nikolaja II rīkojumu 1894. gada 5. decembrī pēc vina tēva imperatora Aleksandra III nāves.

${ }^{3}$ SiguRdS Ziemelis (galv. red.). Latvijas revolucionāro cīnītāju pieminas grāmata. 1. sēj. 1905.-1907. gada revolūcija. 1. dal̦a. Rīga 1976.

${ }^{4}$ SiguRdS ZiemeLIS (galv. red.). Latvijas revolucionāro cīnītāju piemiṇas grāmata. 1. sēj. 1905.-1907. gada revolūcija. 2. daḷa. Rīga 1980.

${ }^{5}$ KĀRLIS LANDERS. 1905. gada priekšvakarā. Maskava 1925.

${ }^{6}$ JĀNIS BĒRZIN̦Š. Bruṇotās sacelšanās problēmas Latvijas pilsētās 1905. gada revolūcijā. In: Latvijas Vēstures Institūta Žurnāls 1992, Nr. 4, 74.-90. lpp.

7 JĀNIS BĒRZIN̦š. Bruṇotās sacelšanās problēmas Latvijas pilsētās 1905. gada revolūcijā (1. turpinājums). In: Latvijas Vēstures Institūta Žurnāls 1993, Nr. 1, 63.-76. lpp.

${ }^{8}$ JĀNIS BĒRZIN̦š. Brunotās sacelšanās problēmas Latvijas pilsētās 1905. gada revolūcijā (nobeigums). In: Latvijas Vēstures Institūta Žurnāls 1993, Nr. 2, 46.-68. lpp.

9 JĀNIS BĒRZIN̦š. Latvijas rūpniecības strādnieku dzīves līmenis. 1900-1914. Rīga 1997.

${ }^{10}$ LìGA LAPA. Kaujinieki un mežabrāḷi 1905. gada revolūcijā Latvijā. Rīga 2018.

${ }^{11}$ VladLen SEMJonovich IZMozik (sost.). Zhandarmi Rossii. Sankt-Peterburg 2002.

${ }^{12}$ Latvijas Nacionālais arhīvs, Latvijas Valsts vēstures arhīvs, Rīga (turpmāk - LNA LVVA), 4569. fonds (Kurzemes guberņas Žandarmērijas pārvalde (Jelgava, Kurzemes guberna)).

${ }^{13}$ Nikolaj Aleksandrovich TrojnickiJ (red.). Pervaja vseobshhaja perepis' naselenija Rosijskoj imperii, 1897 g. t. 19. Kurljandskaja gubernija. Sankt-Peterburg 1905.

${ }^{14}$ JAKov IVANOvich LudMER (red.). Vsja Kurljandskaja Gubernija. Spravochno-adresnoe izdanie Kurljandskago Gubernskago Statisticheskago Komiteta. Mitava 1904.

${ }^{15}$ LidiJA MALAhovsKA. Latvijas transporta vēsture: 19. gs. otrā puse - 20. gs. sākums. Rīga 1998, 66. lpp.

${ }^{16}$ Toms Altbergs. Dzelzceḷi Latvijā. Rīga 2009, 9. lpp.

17 BRIAN Mitchell (ed.). International Historical Statistics. 1750-2005: Europe. London 2007, p. 677.

${ }^{18}$ LUIJS RozENKRANCS. Rakstu krājums par Liepājas rašanos un tirdzniecības attīstību [manuskripts]. Liepāja 1935, 284. lpp.

${ }^{19}$ MaLAhovsKa, Latvijas transporta vēsture, 230. lpp.

${ }^{20}$ ARVEdS ŠvĀBE (galv. red.), ALEKSANDRS BŪMANIS, KĀRLIS DišLERS. Latviešu konversācijas vārdnīca. 12. sēj. Rīga 1935, 24062. sl.

${ }^{21}$ JAKOv IVANOvich LUdMER (red.). Vsja Kurljandskaja Gubernija. Spravochno-adresnoe izdanie Kurljandskago Gubernskago Statisticheskago Komiteta [Chast' vtoraja]. Mitava 1904, s. 267.

${ }^{22}$ Ibidem, s. 268.

${ }^{23}$ Švābe et al., Latviešu konversācijas vārdnīca, 24062. sl. 
${ }^{24}$ ROZENKRANCS, Rakstu krājums par Liepājas rašanos un tirdzniecības attīstību, 65.-66. lpp.

${ }^{25}$ LUDMER, Vsja Kurljandskaja Gubernija. [Chast' vtoraja], s. 88.

${ }^{26}$ KondRATENKO. Voennij port Imperatora Aleksandra III v Libave (okonchanie). In: LeONID AMirhANOv, Vladimir ANDRIENKo (red.). Citadel'. Istoricheskij al'manah 1998, No. 1 (6), s. 13.

${ }^{27}$ TroJNICKIJ, Pervaja vseobshhaja perepis' naselenija Rosijskoj imperii, s. VII.

${ }^{28}$ Pēc 1897. gada Viskrievijas tautas skaitǐšanas datiem, šajā laikā Kurzemes guberņā kopumā dzīvoja 674034 iedzīvotāji, no kuriem 518273 (76,89\%) tika pieskaitīti zemnieku kārtai, savukārt $155761(23,11 \%)$ - pilsētniekiem.

${ }^{29}$ TROJNICKIJ, Pervaja vseobshhaja perepis' naselenija Rosijskoj imperii, s. VII.

${ }^{30}$ Ibidem, s. 2.

${ }^{31}$ NikOlaj AleKSANDROvich TroJnickiJ (red.). Pervaja vseobshhaja perepis' naselenija Rosijskoj imperii, 1897 g. t. 21. Lifljandskaja gubernija. Sankt-Peterburg 1905, s. 2.

${ }^{32}$ FrIEDRICH LENGER. European Cities in the Modern Era, 1850-1914. Leiden 2012, p. 69.

${ }^{33}$ LUDMER, Vsja Kurljandskaja Gubernija. [Chast' vtoraja], s. 168.

${ }^{34}$ LANDERS, 1905. gada priekšvakarā, 14. lpp.

35 Pavel Georgievich Dauge. Revoljucija 1905-1907 gg. V Latvii. Riga 1949, s. 10.

${ }^{36}$ VITĀLIJS ŠALDA. Latvijas sociāldemokrātijas organizatoriskās attīstības dažas tendences 1905. gada revolūcijā. In: 1905. gads Latvijā: 100. Pêtījumi un starptautiskas konferences materiāli, 2005. gada 11.-12. janvāris. Rīga 2006, 209. lpp.

${ }^{37}$ Miķelis Valters. Atmiņas un sapņi. 1. Stokholma 1969, 247. lpp.

${ }^{38}$ DAUGE, Revoljucija 1905-1907 gg., s. 10.

39 JĀNIS KL,AVA. Strādnieku kustības pirmie soḷi Liepājā. In: Revolucionārā kustība Latvijā. Atminas un materiāli I. Latvijas vēstures pētǐšanas biedrības raksti Nr. 1. Rīga 1927, 46. lpp.

${ }^{40}$ LANDERS, 1905. gada priekšvakarā, 14. lpp.

${ }^{41}$ Brošūra "Nost ar jaunajiem". Londona. 1898. Liepājas muzejs (turpmāk - LM), 22410.

42 J. KundZinsš. Strādnieku organizācijas nozīme. 1899. LM, 22412.

${ }^{43}$ Lapiṇa "Atgādinājums Latviešu strādniekiem un strādniecēm" LSS. 06.1899. LM, 22404.

${ }^{44}$ LANDERS, 1905. gada priekšvakarā, 5. lpp.

${ }^{45}$ Policijas departamenta cirkulārs par gaidāmu revolucionāru atgriešanos Krievijas impērijā [krievu val.], 09.11.1902. LNA LVVA, 4569-7-3, 259. lp.

${ }^{46}$ Datumi rakstā norādīti atbilstoši Jūlija kalendāram.

${ }^{47}$ Policijas departamenta ziņojums apakšpulkvedim Aleksandram Mezencevam par nelegāla pasu biroja esamību Liepājā [krievu val.], 20.06.1903. LNA LVVA, 4569-8-44, 2.-3. lp.

${ }^{48}$ E. Rolava vēstule E. Skubikim. 22.12.1903. LM, 22502, 1. lpp.

${ }^{49}$ Ernesta Rolava vēstule E. Skubiḳim. Klaipēda. 26.12.1903. LM, 22499, 1. 1pp.

${ }^{50}$ Ibidem, 3. lpp.

${ }^{51}$ E. Rolava vēstule E. Skubikim. LM, 22501, 1. lpp.

${ }^{52}$ Ibidem, 2. lpp.

${ }^{53}$ Brošūra "Militārisms un strādnieku škira". LM, 22399.

${ }^{54}$ Lapiṇa, hekt. "Liepājas strādniekiem” Liepājas LSDSO. LM, 22407.

${ }^{55}$ Lapina "Baltijas zemniekiem”. LM, 22409.

${ }^{56}$ Brošūra "Car". LM, 22397.

${ }^{57}$ Brošūra “"Gorjuško" Pesnja o russko japonskoj vojne”. LM, 22401, 1. lpp. 
${ }^{58}$ Liepājas cietokšņa žandarmu komandas priekšnieka ziņojums par proklamāciju izplatīšanu cietokšn,a apkārtnē [krievu val.], 27.01.1904. LNA LVVA, 4569-7-221, 5. lp.

${ }^{59}$ Kurzemes guberņas Žandarmērijas pārvaldes priekšnieka palīga Grobiṇas apriṇkīi un Liepājas ostā Aleksandra Mezenceva ziņojums par proklamāciju izplatīšanu [krievu val.], 28.01.1904. Ibidem, 18. lp. v.

${ }^{60}$ Apakšpulkveža A. Mezenceva ziņojums Atsevišķā žandarmu korpusa komandierim par proklamāciju izplatī̌sanu [krievu val.], 28.01.1904. Ibidem, 20. lp.

${ }^{61}$ Kara ostas žandarmu komandas ziṇojums A. Mezencevam par proklamāciju izplatîšanu [krievu val.], 12.02.1904. Ibidem, 71. lp.

${ }^{62}$ Apakšpulkveža A. Mezenceva ziņojuma pielikums - Latviešu valodā izplatītās proklamācijas "Pēdējās ziņas. 3." Tulkojums [krievu val.], [24.03.1904.]. Ibidem, 155. lp.

${ }^{63}$ Kurzemes guberņas Žandarmērijas pārvaldes priekšnieka palīga Grobiņas apriṇkīi un Liepājas ostā Aleksandra Mezenceva ziņ̧ojums par proklamāciju izplatīšanu pie Liepājas sv. Annas baznīcas, 24.09.1904. Ibidem, 419. lp.

${ }^{64}$ ZINAIDA PEREgudova. Departament policii i mestnije uchrezhdenija politicheskogo roziska (1880-1917). In: Zhandarmi Rossii. Sankt-Peterburg 2002, s. 315.

${ }^{65}$ Policijas departamenta cirkulārs par gaidāmu revolucionāru atgriešanos Krievijas impērijā [krievu val.], 09.11.1902. LNA LVVA, 4569-7-3, 259. lp.

${ }^{66}$ Policijas departamenta cirkulārs par gaidāmu revolucionāra atgriešanos Krievijas impērijā [krievu val.], 20.11.1902. Ibidem, 277. lp.

${ }^{67}$ Peregudova, Departament policii i mestnije uchrezhdenija politicheskogo roziska (1880-1917), s. 306.

${ }^{68}$ Ibidem, s. 303.

${ }^{69}$ Ibidem, s. 394.

${ }^{70}$ Policijas departamenta cirkulārs ar prasību ievērot lielāku piesardzību, strādājot ar aǵentiem [krievu val.], 20.03.1903. LNA LVVA, 4569-2-2, 10. lp.

${ }^{71}$ AnNA MinaJlovna MoJsinovich. Politicheskij sisk v Rossii v konce XIX - nachale XX v. Tekst lekcij. Jaroslavl' 2010, s. 34.

${ }^{72}$ Ibidem, s. 35.

${ }^{73}$ Shtati i tabeli: Shtat Libavskoj gorodskoj policii. In: GeorgiJ Georgievich SAVICH (red.). Polnoe Sobranie zakonov Rossijskoj imperii. Sobranie tretie. Tom XI. Sanktpeterburg 1894, s. 21.

${ }^{74}$ DZIDRA Ozolin̦A. Liepājas pilsētas pašvaldība, 1977-1913. Rīga 1990, 252. lpp.

${ }^{75}$ LUdMER, Vsja Kurljandskaja Gubernija. [Chast' vtoraja], s. 27.

${ }^{76}$ AleksandR Mihailovich Plehanov. Otdelnij korpus zhandarmov. [In: Bolshaja rossijskaja enciklopedija]. Pieejams: https://bigenc.ru/military_science/text/2697423 (skatīts 22.01.2019.).

77 MoJsinOvich, Politicheskij sisk v Rossii v konce XIX - nachale XX v, s. 18.

${ }^{78}$ Peregudova, Departament policii i mestnije uchrezhdenija politicheskogo roziska (1880-1917), s. 302.

${ }^{79}$ Ibidem.

${ }^{80}$ Kurzemes guberņas Žandarmērijas pārvaldes priekšnieka palīga Grobiṇas apriṇkīi un Liepājas ostā Aleksandra Mezenceva atskaite par viṇa pakḷautībā esošo darbinieku tēriniiem [krievu val.], 22.10.1904. LNA LVVA, 4569-2-77, 150. lp.

${ }^{81}$ LuDMER, Vsja Kurljandskaja Gubernija. [Chast' vtoraja], s. 32.

${ }^{82}$ Vēlākos avotos cietokšña žandarmu komanda netiek pieminēta, tas, iespējams, norāda uz strukturālām pārmaiņām.

${ }^{83}$ LUDMER, Vsja Kurljandskaja Gubernija. [Chast' vtoraja], s. 33. 
${ }^{84}$ ANDReJ AleKsandrovich Plehanov. Otdelnij korpus pogranichnoj strazhi [In: Bolshaja rossijskaja enciklopedija]. Pieejams: https://bigenc.ru/military_science/text/2697445 (skatīts 22.01.2019.).

${ }^{85}$ BORIS StARKov. Ohotniki na shpionov. Kontrrazvedka Rossijskoj imperii 1903-1914. Peterburg 2006, s. 119.

86 Peregudova, Departament policii i mestnije uchrezhdenija politicheskogo roziska (1880-1917), s. 289.

${ }^{87}$ Informatīvais paziṇojums Kurzemes guberņas Žandarmērijas pārvaldes priekšnieka palīgam par ārzemnieku ierašanos un aizbraukšanu, kā arī izmaiņām to sastāvā par 1902. gada martu [krievu val.], LNA LVVA, 4569-7-4, 35. lp.

${ }^{88}$ Policijas departamenta cirkulārs - ārzemju anarhistu saraksts, kuriem aizliegta iebraukšana Krievijas impērijā [krievu val.], 15.11.1901. LNA LVVA, 35-1-4, 64.-69. lp.

${ }^{89}$ Kurzemes guberṇas Žandarmērijas pārvaldes priekšnieka palīga Grobiṇas apriṇkīi un Liepājas ostā Aleksandra Mezenceva atskaite par viņa pakḷautībā esošo darbinieku tēriniiem [krievu val.], 22.10.1904. LNA LVVA, 4569-2-77, 150. lp.

${ }^{90}$ LUDMER, Vsja Kurljandskaja Gubernija. [Chast' vtoraja], s. 61.

${ }^{91}$ Ibidem, s. 60.

${ }^{92}$ Kurzemes guberņas Žandarmērijas pārvaldes priekšnieka palīga Grobiṇas apriṇ̣̂ī un Liepājas ostā Aleksandra Mezenceva atskaite par personīgo līdzekḷu iztērēšanu laikā no 1904. gada 25. septembra līdz 1. novembrim [krievu val.], 1904. LNA LVVA, 4569-2-77, 157. lp.

${ }^{93}$ Policijas departamenta cirkulārs par revolucionāro organizāciju attīstību pēdējos gados [krievu val.], 13.08.1902. LNA LVVA, 4569-2-2, 1. 1p.

${ }^{94}$ Policijas departamenta cirkulārs ar meklējamo un atrasto aizdomās turamo sarakstiem [krievu val.], 01.02.1902. LNA LVVA, 4569-7-3, 1. lp.

${ }^{95}$ Ibidem, 2. lp.

${ }^{96}$ Policijas departamenta cirkulārs - uzbrukumā Harkovas gubernatoram aizdomās turētā apraksts [krievu val.], 05.08.1902. LNA LVVA, 4569-7-3, 162. lp.

${ }^{97}$ Ibidem, 163. lp.

${ }^{98}$ Policijas departamenta cirkulāra pielikums ar meklēšanā izsludināto personu sarakstu [krievu val.], 10.07.1899. LNA LVVA, 412-2-690, 19. lp. v.

${ }^{99}$ Ibidem, 21. 1p. v.

${ }^{100}$ Abraham Ascher. The Revolution of 1905: A Short History. Palo Alto 2004, p. 23.

${ }^{101}$ Liepājas muzejs, LM 22500, E. Rolava vēstule E. Skubikịim. Berlīne, 10. dec. 1900. g., 1. lpp.

102 Ibidem, 2. lpp.

${ }^{103}$ Policijas departamenta pazinojums Kurzemes gubernas Žandarmērijas pārvaldes priekšniekam par līdzekḷu piešḳiršanu slepeniem tērin̦iem [krievu val.], 08.03.1904. LNA LVVA, 4569-2-77, 44. lp.

${ }^{104}$ E. Rolava vēstule E. Skubiḳim. Berlīne. 10.12.1900. LM, 22500, 2. lpp.

\section{SUMMARY}

As the Liepāja example illustrates, countermeasures taken by the security institutions of the Russian Empire resulted only in short term gains in reducing the activities of revolutionary organisations. These achievements were mainly due to successful work by agents working locally, as well as abroad. Systematically gathered information about revolutionaries in some cases ensured arrests of suspected individuals, however, as the revolutionary organisations became more organised and careful, the ability of security 
institutions to obtain information about them decreased and the information available did not provide the security structures with the results that they desired. A visible example of failure by security institutions in Liepāja was their inability to uncover and stop the work of underground typographies and their incapacity to hold the spread of revolutionary propaganda.

Considering the fact that the essence of revolutionary organisations stemmed from unresolved social issues in the Russian Empire, the activities of security institutions on a local level, in this case - Liepāja and its surroundings, left only a minor impact on the further development of the revolutionary movement. It could be argued that instead in certain aspects (contraband, correspondence of revolutionaries, mobility etc.) it created the opposite effect, allowing local revolutionary organisations to refine their methods, as well as gather support among the population. The situation in Liepāja worsened with the progress of the Russo-Japanese war, leaving a negative impact on the soldiers stationed here, and encouraging revolutionaries to expand their activities.

Thus, despite systematically following the development and activities of revolutionary organisations for years, the outbreak of the revolution, consequent surge of revolutionary activity and rapidly deteriorating security situation in Liepāja and the Russian Empire in general caught the security institutions off guard. A constant lack of information and severe lack of resources to counter revolutionary activity shadowed the work of security structures throughout 1905. 